\title{
The protective effect of kefir as a probiotic on reproductive potential of male rats
}

\section{El- Kewawy, H.E}

Home Economics Dept., Faculty of Specific Education, Mansoura University, Mansoura, Egypt.

\section{ABSTRACT}

$\mathrm{N}$ owadays foods are not purposed to only accept hunger and to give vital nutrients for humans, but also to protect and treated nutrition-related diseases and ameliorate physical and mental status of the consumers. In this respect, probiotic play a prominent role. Thence this study aimed to estimate the chemical constituents of kefir and kefir grain and identify the potential protective effect of probiotic (yoghurt/ kefir milk / kefir grain) to diminish the risk of lead $(\mathrm{Pb})$ intoxication on male rats. Biological study was administered on forty two male rats which allotted into 6 groups involved negative control group (7 rats), normal group consumed kefir milk and four groups which treated $50 \mathrm{mg}$ of lead/kg body weight per day as testicular toxicant and classified into positive control group (+ve), subgroups : yoghurt, kefir milk and kefir grain subgroups. The results revealed that all experimental treatments enhanced liver and kidney functions, antioxidant parameters and testosterone hormone levels, luteinizing hormone (LH) and follicle stimulating hormone level (FSH) the most prominent positive effects were perceived in the group that consumed kefir milk and kefir grain. These acquired results are assured by the histopathological examination. In the present study, the protective effect of kefir milk and kefir grain against lead toxicity in rats was become well. Therefore, this study recommends that consume kefir and supplemented the products with kefir grains to prevent the damage caused by lead contamination.

Key words: probiotic-yoghurt-kefir milk-kefir grain-lead acetate-Sexual Toxicity-antioxidant. 


\section{INTRODUCTION}

Probiotics is marketed as functional foods, where they are consumed for their positive benefits in the digestive system and systemic areas such as vagina, liver or bloodstream. probiotics vie with microbial that can cause disease for restricted number of receptors existent on the surface of the intestinal epithelium (Martta et al., 2007 and Kemgang et al.,2014) and steadiness of intestinal penetrability wall, therefore limitation existence of pathogens and removing strange antigens by producing short fatty acids to feed the cells lining of the colon, lifting the acid in the colon, and producing antibiotic-like fluids that act as a protective barrier against harmful bacteria, and improve the immunity system (Markowiak and zewska, 2017).

Probiotics is living microorganisms, on being utilized in sufficient quantity, Benefits are granted on healthiness host like enhancement of the capacity intestines and amelioration of the lactose sensitivity and decrease the value of lipids in serum. The cells of the intestinal bacteria can bind by cholesterol and bile acids, which inhibits the absorption of total cholesterol and reduces its level in the blood. The bacterial cells actively process the bile salts and release about half of the bile from their salts that reach the small intestine. This is followed by an increase in the output of bile salts during the waste, which in turn reflects the improvement of lipid rate in the blood (Kumar et al. 2012). Yoghurt and kefir were considered as functional foods containing probiotics. Protein, phosphorus, calcium, thiamin (vitamin B1), riboflavin (vitamin B2), niacin, and vitamin B12, are found in yoghurt at an excellent rate, Yoghurt is a valuable source of folic acid, zinc and magnesium (Madhu et al., 2013).

Kefir is potential antioxidants which react directly with an extensive variety of species responsible for oxidative damage. The antioxidant capacity of kefirs may be attributed to their proton- contribute capacity, their 
decreasing force and superoxide dismutase (SOD)-like action as represented through 1,1-diphenyl2-picrylhydrazyl (DPPH) and superoxide radical searching and lipid per-oxidative restraint comes about. Accordingly, kefir is probably the most important dietary supplement because of its effective role as a natural antioxidant for humans. (Nurliyani et al., 2015).

Lead is a non-essential element that found in nature. It is known that heavy metal ions cause a great risk to the environmental system in very low doses on account of their high toxicity stability and accumulation and transfer in food chains considered among the main environmental pollutants, along with mercury and cadmium, which is one of the most harmful effects on human (Haryanto, 2016). Sub-chronic oral lead intoxication may affect testes and body organs for numerous years even in absenteeism of continual exposure (Adhikari et al., 2001).
Accumulation of lead in tissues was due to cellular damage by oxidative stress after excessive formation of reactive oxygen species and decreased in the activities of the cellular antioxidant system (Gandhi et al., 2017). Lead exposure related with decreased enzyme activities in testis and disruption of sperm formation and histoarchitecture (Boscolo et al., 1988). In addition, BaSalamah et al., (2018) found that rats which chronically the exposed to $\mathrm{Pb}$, showed a significantly increase in tissue contents of the heavy metal that concur with significantly reduce in rate of $25-\mathrm{OH} \mathrm{VD}$ and $\mathrm{Ca} 2+$ in serum .

Co-administration of probiotics alone or with dandelion extract has the ability to prevention of testicular toxicity induced by arsenic in rats and improved kidney and liver functions, while the dandelion extract alone did not occur this (Al-Damegh et al., 2014). Rosa et al., (2014) demonstrated that kefir supplementation with high and normal dose $(3.5 \& .7 \mathrm{ml})$ for 1 
month in Wister rats did not observe injurious effects in growth, hematology, and blood chemistry in rats ,thus consumption of kefir is safe. Milk kefir showed marked curative benefits in $\mathrm{HCV}$ patients by lowering viral load, mitigating the altered liver function and amelioration of lipid profile. The ameliorative effects of milk kefir in $\mathrm{HCV}$ patients may be due to its antioxidant, anti-inflammatory and immune-stimulatory effects (Morsy et al., 2014).

Lead is a toxic heavy metal that raise the level and freeing of free radicals and reduces the activity of the enzymatic and nonenzymatic antioxidant system to respond to oxidative stress. The goal of this study was to explore the protective effect of kefir against the effect of lead on oxidative stress and damage in rat testis. Because of, probiotic has the ability to act as antioxidants; also, it is the main source of calcium and vitamin D. Previous studies noted that the role of calcium and vitamin $\mathrm{D}$ in the removal of toxicity resulting from lead. The researchers had observed that preventive effect for vitamin $\mathrm{D}$ against $\mathrm{Pb}$-induced testicular and renal damage by antioxidative and antiinflammatory mechanisms

(BaSalamah et al., 2018).

\section{MATERIALS \&METHODS}

\section{Materials:}

Forty two male albino rats of Sprague Dawley strain were bought from Helwan ranch of experimental animals, Helwan, Egypt. Mean weight of rats ranged from 110 to $115 \mathrm{~g}$. The basal diet was implemented in accordance with (NRC, 1995). Fresh cow's milk was taken from the herd of the dairy cattle at Faculty of Agriculture, Mansoura University, and Mansoura, Egypt. Lead acetate, all chemical Diagnostic kits were obtained from ElGomhoria Company, El-Mansoura city, Egypt.

Cultures: Yoghurt starter culture (YC-X11 DIP 50u) Lactobacillus delbrueckii subsp contains and Streptococcus thermophilus. bulgaricus was gotten from Chr. Hansens 
Laboratories, Denmark and activated at $42^{\circ} \mathrm{C}$ utilizing $12 \%$ sterilized reconstituted skim milk. After incubation at $42^{\circ} \mathrm{C}$ for $4-5 \mathrm{~h}$, the obtained working culture was freshly utilized. Kefir grains were kindly provided by the Food Technology Research Institute, Agricultural Research Centre, Giza, Egypt.

\section{Methods:}

\section{Kefir preparation}

Kefir grains were cleaned with distilled water and vaccinated in whole cow's milk during incubation at room temperature. The kefir milk was made by inoculation of $(2 \% \mathrm{w} / \mathrm{v})$ kefir grains into pasteurized milk (milks heated to $95{ }^{\circ} \mathrm{C}$ for $15 \mathrm{~min}$ and immediately cooled to $23{ }^{\circ} \mathrm{C}$ ) and incubated at $24{ }^{\circ} \mathrm{C}$ for 24 hours, then the grains were taken away from the fermented milk by filtration with a plastic sifter, washed, and kept for following preparation (Kefir was added at different concentrations and incubated for several hours. Then, the concentration and number of incubation hours were selected according to the lowest percentage of alcohol produced by fermentation). This procedure was rehashed day by day all through the 45 day of the trial time frame.

\section{Production of Yoghurt}

Cow's milk (protein $3.72 \%$, fat $3 \%$, total solids $12.3 \%$ and acidity $0.17 \%$ ) was utilized then heated to $95^{\circ} \mathrm{C}$ for $15 \mathrm{~min}$. and after that quickly cooled to $45^{\circ} \mathrm{C}$. The working yoghurt culture was added at the percentage of $2 \% \quad(\mathrm{w} / \mathrm{v})$. The inoculated mix was packed into $2.0 \mathrm{~kg}$ plastic cups and incubated at $43^{\circ} \mathrm{C}$. The incubation was finished at $\mathrm{pH}$ 4.5. At this point, the yoghurt was stored in a refrigerator $\left(5 \pm 1^{\circ} \mathrm{C}\right)$.

\section{Analytical Methods:}

Approximate chemical compositions of kefir milk and kefir grain (moisture, ash, fat and crude protein) were estimated by the techniques for the (A.O.A.C. 2007). Whereas, total carbohydrates were estimated by subtracting the difference from initial weight of the samples 
follows, as: Carbohydrates $\%=$ $100-(\%$ moisture $+\%$ protein + $\%$ fat $+\%$ ash). Total phenols and total flavonoid were estimated by Slinkard and Singleton (1977) and Zhishen et al.,( 1999 ) . Alcohol was determined in the fermented milks according to Caputi et al., (1968).

\section{Experimental design:}

Animals were kept in the laboratory in plastic cages under constant temperature $(24 \pm 2 \mathrm{C})$. All rats were nourished on basal diet only for seven days before beginning the trial for acclimatization. After acclimatization period, Forty two male rats were allotted into 6 groups (7rats/treatment) at random; the negative control (C-) group was fed the basal diet only. Group Normal kefir milk (N.K.M) fed on basil diet plus kefir milk dosage of $1.8 \mathrm{~mL}$ for 45 day. The rest of the rats except (7 rats) were administered lead acetate 50 $\mathrm{mg} / \mathrm{kg}$ rat according to (Owolabi et al., 2012). Positive control $(\mathrm{C}+)$ group was fed the basal diet in plus lead acetate orally once in a day for 35 days. While the other 3groups were fed diets plus yoghurt (Y) , Kefir milk (K.M) and Kefir grain (K.G). The rat yoghurt and kefir milk dosage of $1.8 \mathrm{~mL} /$ day once in a day for 45 days according to Punaro et al.,(2014) . Kefir grain was included at $40 \mathrm{~g} / \mathrm{kg}$ of standard diet according to Can et al., (2012). Lead acetate $50 \mathrm{mg} / \mathrm{kg}$.bw were given on $10^{\text {th }}$ day, one hour after the yoghurt, kefir milk and Kefir grain administration for 35 days.

Growth performance and feeding were noticed by enrollment daily feed intake, body weight gain and feed efficiency ratio (FER) as per Chapman et al., (1950) as mean daily body weight gain divided by mean daily food intake .The rats were sacrificed after 45 days blood collected and centrifuged at 3,000 rpm for 15 min to get serum, and testis were compiled for biochemical analysis and histopathological examination.

\section{Biochemical analysis of serum:}

Uric acid was assessed in serum as indicated to the method 
by Fossati et al., (1980). Urea was assessed according to Patton and Crouch (1977). Creatinine was measured by Bonsens and Taussky (1984). Aspartate aminotransferase (AST) and alanine aminotransferase (ALT) were measured by Reitman and Frankel (1957). Serum testosterone and follicle stimulating hormone levels (FSH) in the serum were dictated by a catalyst connected immunosorbent measure (ELISA) utilizing business packs as depicted by Wilke and Utley (1987) and Ballester et al., (2004). Luteinizing hormone (LH) was measured by radioimmunoassay as indicated by the strategy portrayed by Schams and Karg (1969).

Detection of oxidative in testes tissue: Reduced glutathione (GSH) was resolved by Sedlak and Lindsay (1968). Lipid peroxidation (malondialdehyde) was estimated as portrayed by Ohkawa et al., (1979). Superoxide dismutase SOD activity was measured by Marklund (1985).

\section{Histopathological examinations}

were performed on testicular tissues as described by Bancroft et al., (1996).

\section{Statistical analysis:-}

Results obtained from this study have been described as mean \pm standard deviation (mean \pm SD).Data were analyzed using one way classification, analysis of variance (ANOVA) test. The differences between means were tested for significance using least significant difference (LSD) test at $<0.05$ (Snedcor and Cochran, 1967).

\section{RESULTS \& DISCUSSION}

Moisture, Protein, fat, ash, and carbohydrates of Kefir milk, Kefir grain yoghurt were identified and schedule in Table (1). It was plainly that Moisture , Protein, fat, ash , carbohydrates, total phenol, total Flavonoid, $\mathrm{pH}$ and Ethanol were $87.62 \%, 3.03 \%$, $3.15 \%, 0.043 \%, 5.77 \%, 0.84$ $\mathrm{mg} / 100 \mathrm{~g} \quad, 0.16 \mathrm{mg} / 100 \mathrm{~g}, 4.9$ and 0.065 respectively for Kefir 
milk while Moisture, Protein, fat, ash , carbohydrates , total phenol and total Flavonoid of Kefir grain were $9.53 \%, 10.75 \%$, $7.88 \%, \quad 2.03 \% .18 .71 \%, \quad 2.03$ $\mathrm{mg} / 100 \mathrm{~g}$ and $0.88 \mathrm{mg} / 100 \mathrm{~g}$ respectively. Constituents of kefir milk from fat, protein, carbohydrates and ash was similar to Hallé et al.,(1994), while , Libudzisz and Piatkiewicz (1990) noted that kefir milk contain ethanol of 0.035 $2.000 \%$. A study done by Garrote et al., (1997) found that chemical composition of kefir grains were $2 \mathrm{~g} \mathrm{~kg}-1$ lipid, $30 \mathrm{~g}$ kg-1 .protein, $7 \mathrm{~g} \mathrm{~kg}-1$ ash, $60 \mathrm{~g}$ kg-1 sugars and 890-900 g kg-1 water. However, Libudzisz and Piatkiewicz (1990) reported that dray mass of fresh grain $10-16$ $\mathrm{g} / 100 \mathrm{~g}, 30 \mathrm{~g} / 100 \mathrm{~g}$ protein and 25 $50 \mathrm{~g}$ carbohydrate. Thence, this variation in values obtained can be attributed to the different kefir species.

Data in table (2) illustrated that, rats in normal control and normal plus kefir milk groups had a significant increase in values of body weight gain ,feed intake and feed efficiency ratio compared to rats intoxicated by lead acetate control $(+$ ve) and probiotic groups; yogurt, kefir milk and kefir grain. A probiotic groups showed a significant higher values of the feed intake ,body weight gain and feed efficiency ratio compared to control (+ ve) group. The results of the other studies showed that treatment with lead acetate caused decrease in the growth rate in experimental animals when lead acetate was orally supplementation, which has adverse effects on body weight gain and feed intake and liver function experimental animals (Ali et al., 2010; Seddik et al., 2010). Lead acetate causes dysfunction in the absorption and metabolism of some important nutrients so that might be the cause of body weight loss (Marija et al., 2004). Comparable results were likewise reported by Ibrahim et al., (2012), " Lead causes lowering in growth rate for rats because of could be related by some factors, one of that is imbalance metabolism created by impairing zinc status in zinc- 
dependent enzymes which are vital for many metabolic processes" .Whilst, Goni,et al., (2016) explained that whole milk might be useful in reducing the body burden of lead toxicity.

From results in table (3), it could observe that there was significant improvement in uric acid, urea and creatinine in all groups that feed on probiotics to study their protective effect., Uric acid, creatinine, , urea level AST and ALT were significantly elevated in control (+ve) group comparing with normal control group. However protective effect group with yogurt, kefir milk and kefir grain significantly reduced these parameters compared to positive group. It appears from the present results that kefir milk and kefir grain were safe and improves renal and liver functions.

Daily consumption of 500 $\mathrm{mL}$ of kefir was reported to stabilize metabolism, positively effect on liver, gallbladder, and renal function, and blood circulation (Liu et al., 2006). Studies have resulted that kefir was more effective than vitamin $\mathrm{E}$ by increasing levels of glutathione, glutathione peroxidase and reduced lipid peroxidase in the rat model of injury oxidation caused by $\mathrm{CC} 14$ (Guven and Gülmez.,2003) .

Çenesiz et al., 2008 observed the positive biochemical effects of kefir on oxidative stress; the antioxidant effect on the formation of abnormal coldness in the colon caused by azoxymethane was higher in rats consumption kefir. Alsayadi et al., (2013) assured that water kefir have antioxidants action it a best scavenger of free radicals from body. For that, it is possible that kefir can restrain the degradation of the mitochondrial membrane,

\section{Mogheth et al., (2017)} found that kefir was characterized by protection against hepatic toxicity caused by $\mathrm{CCl} 4$ and an antimicrobial activity against pathogenic microorganisms. These protective effects were demonstrated through its antiinflammatory effect and inhibition of $\mathrm{CCl} 4$ movement and improved 
liver capacity. In this way, kefir may be applied in clinical application in the avoidance as well as treatment of liver danger. Probiotic supplements have attracted the attention of the researchers' consequent to its prospective to detoxify the gastrointestinal tract. A study done by Imani Fooladi et al., (2013) reported that healthy status of the gastrointestinal tract is in a symbiotic relation with that of the liver. This is consequent to the vital role by the microflora resident of the intestinal lumen to the function of the hepatocytes, in which alterations to per se may reason liver dysfunctions.

$$
\text { Results in table }
$$

indicated that administration of lead acetate in positive control group showed significant diminishing in serum testosterone (T), Follicle Stimulating Hormone (FSH) and luteinizing hormone (LH) compared to (-ve) control group. All groups that feed on probiotics to study their protective effect (yoghurt, kefir milk and kefir grain) had a significantly elevated in serum testosterone,
FSH and LH levels compared with the positive control group.

Lead reproductive toxicity may be associated with the extreme creation of Reactive Oxygen Species (ROS), an issue that has received more attention lately. ROS, inhibits enzyme reactions, inhibits the creation of sulfhydryl antioxidants, destroys nucleic acids and hinders DNA repair, and additionally, starting lipid peroxidation in cellular membranes. Lead promotes the generation of hydrogen peroxide and induces oxidative stress (Vaziri and Khan 2007).

These information might be because of the impacts of oxidative stress and dopamine on male sexual capacity, the larger part of microorganisms demonstrate cancer prevention agent conduct, wiping out the abundance oxygen free radicals and creating superoxide dismutase, or glutathione (Songisepp et al., 2004). The yogurt microorganisms Lactobacillus delbrueckii and Streptococcus thermophiles 
repressed peroxidation of lipids by rummaging the responsive oxygen radicals, for example, hydroxyl radical, or hydrogen peroxide (Ling and Yen 1999). BaSalamah et al., (2018) confirmed that vitamin D3 significantly minify $\mathrm{Pb}$-induced tissue damage in testis and kidney. Tissue regeneration or safeguard was related by significant raise of anti-oxidative indications. Henceforth, it can be hypothesize that yoghurt and kefir treatment can offer protection against pbinduced oxidative stress in vivo because of probiotic was rich source of vitamin D.

Results in table (5) showed that oral administration of lead acetate in control(+) group revealed significant reduction in superoxide dismutase (SOD) glutathione (GSH), and increase in malondialdehyde level compared to (-ve) control group. All groups that feed on probiotics to study their protective effect (yogurt, kefir milk and kefir grain) enhanced the active of testicular (SOD), malondialdehyde and (GSH) antioxidant enzymes compared to positive control group. These outcomes were in concurrence with Ozcan et al., 2009, they reported that on supplementing diet by kefir with or without lead, (SOD) and (GSH) levels became resembles control group and Vit. E raised by kefir supplementation. Accordingly, the oxidative damage induced by lead and supported oxidative system may be indeed preventing by kefir.

Vitamins A, conjugated linoleic acid (CLA), B-carotene , vit.E and coenzyme Q10 are the main antioxidants in milk fat and other compounds with antioxidant characteristics comprise vitamin D3, phospholipids and probably, 13-methyl-tetradecanoic acid (German and Dillard 2006; Baldi and Pinotti 2008). Vitamin E (a-tocopherol) and conjugated linoleic acid (CLA) are the more active antioxidants in milk fat. The antioxidant strength of vitamin $\mathrm{E}$, shown by its capability to deactivate singlet oxygen, is reinforced by B-carotene and vitamin $\mathrm{A}$ which are most active than vitamins $\mathrm{E}$ and $\mathrm{C}$. Vitamins $\mathrm{A}, \mathrm{E}$ and D3 are properties by 
high levels of thermal stability and they stay active in each dairy products without of the utilized thermal treatment method (Claeys et al., 2014). Mustafa and Abdullah (2009) concluded that probiotic decreased lead acetate absorption and reduced its toxic action on studied parameters in chicks.

The results obtained in table $(3,4 \& 5)$ referred to it is possible to note that there is a link between dysfunction in the liver and kidney function and also the lack of hormone testosterone and can be consistent with Sinclair et al., 2015 said that in men with cirrhosis, decline in testosterone value in parallel with the severity of liver disease deterioration. Testosterone levels (T) are generally low in men with advanced liver disease, and gradually decrease with increased acuteness of liver disease (Handelsman et al.,1995) various clinical symptoms of advanced liver disease, like as anemia, sarcobinia, bone disease, and gynecomastia are also a phenomenon in gonadal insufficiency, thence, decrease in $\mathrm{T}$ levels may has recently been specified as an independent prophetic indication in cirrhosis(Grossmann et al., 2012), moreover, liver diseases in human are related with several hormone disorders, like as decreased serum levels of cortisol, T3, FSH , testosterone and insulin in males (Barreca et al., 1983; Kolster et al., 1990), thence, this study recommends further studies illustrating this relationship.

\section{Histopathological Results:}

Results obtained from this study were assured by the histopathological examination. Pict.(1) shows that the testis of rat from the control (- ve) group showed normal seminiferous tubules normal spermatogenic cells and the tubules contain mature spermatid. Meanwhile, the testis of rat from the control (+ve) group was exhibiting destruction of some spermatogenic cells of the seminiferous tubules with interstitial edema as shown in Pict. (2) the testis of normal rat from kefir milk group revealed normal 
structure of seminiferous tubules as shown in Pict. (3). Testis of rat from yogurt group showing, few degeneration changes in the spermatogenic cells with separation of the seminiferous tubules as shown in Pict. (4).The testis of rats from kefir milk revealing normal spermatogenesis with few reductions of mature sperm in seminiferous tubules as shown in Pict. (5). the testis of rats from kefir grain showing activation of spermatogenesis and mature spermatid as shown in Pict. (6). Lead occurred testicular damage in rats; This is supported by Jegede et al., (2015) and Anjum and Reddy (2015), in which they stated ,Chronic consuming of $\mathrm{Pb}$ led to interstitial degeneration and reduce numbers of viable Sertoli, Leydig and germ cells simultaneously, that shown in testicular tissue with significantly decrease serum testosterone. This might be due to the ability of Lead ions to generate reactive oxygen species competent of soft tissue break-down according to (Dare et al., 2012). Effect of lead toxic on testes is attributed to the output of extreme reactive oxygen species (ROS), (Mariola et al., 2004). These results coped with Aprioku and Obianime (2014) they noted that toxicity pb led to atrophy in testis and ultimately affected on their physiological function. The improvement in histopathological examination results of groups which consumed probiotic agree with (Amdekar and Singh, 2016), they found that the intake of Lactobacillus acidophilus would protect the testis from damage caused by oxidation. The treatment of Lactobacillus acidophilus can be detected by removing the free radicals that have been created, thus it has the ability to protect the testis from oxidative damage. This improvement in histopathological results can be attributed to probiotics and its contains of vitamin $\mathrm{A}$ and $\mathrm{D}$ and $\mathrm{E}$, and its effective role as a natural antioxidant, is congruent with this notion Momeni et al.,2012 for they found that vitamin $\mathrm{E}$ has the ability to improving the histopathological changes caused 
by sodium arsenite in the testis, vit. E alone promoted the height and the average of diameter of seminiferous tubules and decreased the average diameter of seminiferous tubule's lumen in comparing by normal control animals. Is consistent with this notion, vitamin $\mathrm{E}$ is called an antisterility vitamin

\section{CONCLUSION}

Present study indicates that pb-induced testicular toxicity in male rats. The pretreatment of pbintoxicated groups with kefir restored the lipid peroxidation, the antioxidant enzymes status and the histoarchitecture of pb-damaged testes. The protective effect of kefir may be because of its antioxidant property and detoxification capacity.

\section{REFERENCES}

\section{Adhikari N; Sinha N; Narayan} R; Saxena DK (2001):

Lead-induced cell death in testes of young rats. $J$ Applied Toxicol; 21:275-7.

\begin{abstract}
Al-Damegh MA; Zeitoun MM and Abdel-Salam AM (2014):

The Role of Fermented Milk Containing Probiotic, Dandelion as Prebiotic or their Combination on Serum Metabolites, Enzymes, Testosterone and Testicular Histopathology of Arsenic-Intoxicated Male Rats. Journal of Basic \& Applied Sciences, 10, 492-503
\end{abstract}

\begin{abstract}
Ali MA; Awal MA; Mostofa M; Islam MA and Ghosh A (2010):

Effects of selenium and vitamin B6 with their combination lead acetate induced toxicities in long evan rats. Bangladesh Journal of Veterinary Medicine, 8: 63-73.
\end{abstract}

\section{Alsayadi M; Al Jawfi Y; Belarbi $M$ and Sabri F (2013):}

Antioxidant potency of water kefir, Journal of Microbiology, Biotechnology and Food 
Sciences2013: 2 (6) 24442447.

\section{Amdekar S and Singh V (2016):}

Lactobacillus

acidophilus maintained oxidative stress from reproductive organs in collagen-induced arthritic rats. J Hum Reprod Sci;9:41-6.

Anjum, R. M. and Reddy, S.P.(2015):

Recovery of lead-induced suppressed reproduction in male rats by testosterone, Andrologia 4 $7,560-7$

AOAC (2007):

Official Methods of Analysis, $\quad 18$ Ed. Association of Official Analytical chemists, Gaithersburg, MD, USA.

\section{Aprioku JS and Obianime AW} (2014):

Evaluation of the effects of Citrus aurantifolia (Lime) Juice in Lead-induced
Hematological and Testicular Toxicity in Rats, Pharmacologia 5(1):3641.

Baldi A and Pinotti L (2008):

Lipofilic

microconstituents of milk, Advances in Experimental Medicine and Biology 606 109-125.

Ballester J; Munoz MC; Dominguez J; Rigau $\mathbf{T}$; Guinovart JJ and Rodriguez JE (2004):

Insulin-dependent diabetes affects testicular function by FSH -linked mechanisms. J.Androl. 25(5): 706-719.

Bancroft JD; Stevens A and Turner DR (1996):

Theory and Practice of Histological Technique 4th Ed. New York, Churchill, Livingstone.

Barreca T; Franceschini R; Messina V; Bottaro $P$ and Rolandi E (1983): 


$\begin{array}{lr}\text { Changes in } & \text { pituitary } \\ \text { secretion } & \text { after } \\ \text { administration } & \text { of } \\ \text { branched-chain } & \text { amino } \\ \text { acids to patients with } & \text { cirrhosis. } \\ \text { hepatic } & \mathrm{J} . \\ \text { European } & \text { Clin.Pharmacol., 25, } 763- \\ 766 . & \end{array}$

BaSalamah MA; Abdelghany AH; El-Boshy M; Ahmad J; Idris $S$ and Refaat $B$ (2018):

Vitamin D alleviates lead induced renal and testicular injuries by immunomodulatory and antioxidant mechanisms in rats. Scientific Reports, $8: 4853$

Bonsens KE and Taussky DH (1984):

Determination of serum creatinine .J Chem Inv, 27: 648-660.

Boscolo P; Carmignani M; Sacchettoni - Logroscino G; Rannelletti FO; Artese L and Preziosi P ( 1988):
Ultrastructure of the testes in rats with blood hypertension induced by long-term lead exposure, Toxicol Lett; 41:129-37.

J. Can E; Kurtoğlu İZ; Benzer F; Erişir M; Kocabaş M; Kızak V; Kayım $M$ and Çelik HT (2012):

The Effects of Different Dosage of Kefir with Different Durations on Growth Performances and Antioxidant System in the Blood and Liver Tissues of Çoruh Trout (Salmo coruhensis). Turk. J. Fish. Aquat. Sci. 12: 277-283.

\section{Caputi A; Ueda M and Brown T (1968): \\ Spectrophotometric \\ determination of ethanol in wine,. Am J Enol Vitic 19: 160-65.}

Çenesiz S; Devrim AK; Kamber $U$ and Sozmen M (2008):

The effect of kefir on glutathione (GSH), malondialdehyde (MDA) and nitric oxide (NO) levels 
inmice with colonic abnormal crypt formation (ACF) induced by azoxymethane (AOM). Dtsch Tierarztl Wochenschr; 115: 15-9.

Chapman DG; Gastilla R and Campbell TA (1950):

Evaluation of protein in food. Method for the determination of protein efficiency ratio Can., $J$. Biochem. Physio. I (37) 679-686.

Claeys WL; Verraes C; Cardoen S; De Block J; Huyghebaert A; Raes K; Dewettinck $K$ and Herman $L$ (2014):

Consumption of raw or heated milk from different species: an evaluation of the nutritional and potential health benefits. Food Control 42 188-201.

Dare BJ; Chukwu RO; Oyewopo AO; Makanjuola VO; Olayinka PO; Akinrinade ID; Olaniyan TO; Omotoso OD;

\section{Shafe MO; Ogundele OM;} Beremako $O$ and Adeh MN (2012):

Histological Integrity of the Testis of Adult Wistar Rats (Rattus novergicus) Treated with Garcinia kola. Reprod Sys Sexual Disorders 1:113.

\section{Fossati P; Prencipe L and Berti G (1980): \\ Use of 3, 5 dichloro-2- hydroxybenzene sulfonic acid /4-aminophenazon chromogenic system in direct enzymatic assay of uric acid in serum and urine. Clin. Chem., 26: 227-231.}

Gandhi, J. Hernandez ,R.1.J ; Chen,A.and Smith,N.L.(2017):

Impaired hypothalamicpituitary-testicular axis activity, spermatogenesis, and sperm function promote infertility in males with lead poisoning. Zygote 25, 103-110. 
Garrote GL, Abraham AG and De Antoni GL (1997):

Preservation of Kefir Grains, a Comparative Study. Lebensemittel Wissenschaft und Technologie, 30, 77-84.

German J B and Dillard C J (2006):

Composition, structure and absorption of milk lipids: a source of energy, fat-soluble nutrients and bioactive molecules. Critical Reviews in Food Science and Nutrition 46 57-92.

Goni MU; Siddiqui MSI; Rashid MH; Islam K; Moonmoon S; Ahmed $S$ and Mustafa $M$ (2016):

Effect of lead acetate alone and in combination with whole milk (Star ship®) on body growth and liver functions in an experimentally induced lead toxicity in rat, Asian J. Med. Biol. Res., 2 (2), 183-189;
Grossmann M; Hoermann $\mathbf{R}$ and Gani L (2012):

Low testosterone levels as an independent predictor of mortality in men with chronic liver disease. Clin. Endocrinol. $\quad($ Oxf $) ; \quad$ 77: 323-8.

Guven A and Gülmez M (2003):

The effect of kefir on the activities of GSH-Px, GST, CAT, GSH and LPO levels in carbon tetrachlorideinduced mice tissues. $J$ Vet Med $B$ Infect Dis Vet Public Health; 50: 412- 6.

\section{Hallé C; Leroi F; Dousset X and Pidoux M (1994):}

Les kéfirs: des associations' bactéries lactiqueslevures. In Roissart, De H., Luquet, F.M. (Eds.), Bactéries lactiques: Aspects fondamentaux et technologiques. Vol. 2. Uriage, France, Lorica, pp: 169-182. 
Handelsman DJ; Strasser S; McDonald JA; Conway AJ and McCaughan GW (1995):

Hypothalamic-pituitarytesticular function in endstage non-alcoholic liver disease before and after liver transplantation. Clin. Endocrinol. (Oxf); 43: 331-337.

Haryanto B (2016):

Lead exposure from battery recycling in Indonesia. Rev Environ Health 31, 6-13.

Ibrahim NM; Eweis EA; ElBeltagi H S and Abdel-Mobdy Y E ( 2012):

Effect of lead acetate toxicity on experimental male albino rat. Asian Pacific Journal of Tropical Biomedicine 2: 41-46.

Imani Fooladi AA; Mahmoodzadeh Hosseini $\mathbf{H}$; Nourani MR; Khani $S$ and Alavian SM (2013):

Probiotic as a novel treatment strategy against liver disease. HepatMon 13(2):e7521.

Jegede AI.; Offor U; Azu OO and Akinloye $O$ (2015):

Red Palm Oil Attenuates Lead Acetate Induced Testicular Damage in Adult Male SpragueDawley Rats. Evid Based Complement Alternat Med, Volume, Article 7pages. http://dx.doi.org/10.1155/2 015/13026.

Kemgang TS; Kapila S; Venkatesa SP and Kapila $R$ (2014):

Cross-talk between probiotic lactobacilli and host immune system. $J$ Applied Microbiol 117:303-319.

Kolster J; Castro de Kolster C; Bustillos R; de Pool I and Pepe $M$ (1990):

Pituitary-gonadal

hormonal evaluation in male patients with alcoholic liver cirrhosis. G.E.N. 44: 203-208. 
Kumar M; Nagpal R; Kumar R; Hemalatha R; Verma V; Kumar A; Chakraborty C; Singh B; Marotta F; Jain S and Yadav H (2012):

Cholesterol- lowering probiotics as potential bio therapeutics for metabolic diseases. Exp Diabetes Res.:1-14.

\section{Libudzisz $\mathrm{Z}$ and Piatkiewicz A} (1990):

Kefir production in Poland. Dairy Industries International 55: 31-33.

\section{Ling MY and Yen CL (1999):}

Antioxidative ability of lactic acid bacteria. J.Agric.Food Chem. 47, 1460-1466.

\section{Liu JR; Wang SY; Chen MJ;} Chen HL; Yueh PY and Lin CW (2006):

Hypocholesterolaemic effects of milk-kefir and soya milk-kefir in cholesterol-fed hamsters. Br J Nutr; 95: 939-46.
Madhu M; Shiva Prakash and Neetu (2013):

Yoghurt is excellent vehicle for travelling probiotics to public health . International Journal of Food And Nutritional Science, Vol.2, Iss.1,126137.

Marija V; Piasek M; Blanusa M; Saric M; Juresa $D$ and Kostial K (2004):

Succimer treatment and calcium supplementation reduce tissue lead in suckling rats. $J$ Appl Toxicol24, 123-128.

Marklund SL (1985):

Pyrogall of autooxedation. In: Greenwald RA(ed) Handbook of Methods for Oxygen Radical Research. Boca Raton, Florida, CRC Press pp: 243-247.

Markowiak $P$ and zewska KS (2017):

Effects of Probiotics, Prebiotics, and Synbiotics 
on Human Health.

Nutrients, 9, 1021, 1-30.;

Mariola M.; Michalska T and Wiszniewska B. (2004):

Detection of lead-induced oxidative stress in the rat epididymis by chemiluminescence.

Chemosphere, 57: 15531562.

Martta F; Harada M; Goh K L; Lorenzetti A; Marandola $P$ and Minelli E (2007):

In vitro study on the mechanisms of action of a novel phytotherapeutic compound against human hepatoma cells. Ann Hepatol, 6, 111-6.

Mogheth SAE; El-Gendy AO; Sultan $S$ and El-Nesr KA (2017):

Investigation and

Characterization

of

Biologically

Active

Compounds Recovered from Kefir (A Probiotic Fermented Milk). J Prob Health 5: 173.

\section{Momeni HR; Oryan S and} Eskandari N (2012):

Effect of vitamin $\mathrm{E}$ on sperm number and testis histopathology of sodium arsenite- treated rats. Reproductive Biology ,12( 2) : 171-181.

Morsy BM; Mahmoud AM; Zanaty MI; Abdel-Moneim A and Abo-Seif MA (2014):

Beneficial Effects Of Milk Kefir In Patients With Chronic Hepatitis C Virus Infection. Int. J. Bioassays, 3 (06), 3086-3091.

Mustafa NG and Abdullah ST (2009):

Effects of Lead Acetate and Probiotic on Some Physiological Parameters in Broiler Chicks, J. Raf. Sci., Vol. 20, No.2, pp 17.

NRC (1995):

National Research council:

Nutrient requirements of laboratory animals. Fourth 
revised edition, PP.29-30

National Academy Press.

Washington, DC.

Nurliyani; Eni Harmayani and Sunarti (2015):

Antidiabetic Potential of Kefir Combination from Goat Milk and Soy Milk in Rats Induced with

Streptozotocin-

Nicotinamide. Korean $J$. Food Sci. An. Vol. 35, No. 6, pp. 847:858.

Ohkawa H; Ohishi N; Yagi K (1979):

Assay of lipid peroxides in animal tissues by thiobarbituric acid reaction. Anal Biochem 95: 351-358.

Owolabi JO; Ghazal OK; Williams FE and Ayodele EO(2012):

Effect of Moringa oleifera (Drumstick) leaf extracts on lead induced testicular toxicity in adult Wistar rat (Rattus novergicus) Int $J$

$$
\begin{aligned}
& \text { Biotech Biomed } \\
& \text { Res.;2(12):4003-4009. }
\end{aligned}
$$

Ozcan A; Kaya N; Atakisi O; Karapehlivan M; Atakisi $\mathbf{E}$ and Cenesiz S (2009):

Effect of kefir on the oxidative stress due to lead in rats. J Appl Anim Res 35, 91-93.

Patton C and Crouch S (1977):

Enzymatic colorimetric method for determination of urea in serum. Anal. Chem., 49: 464-269.

Punaro GR; Maciel FR; Rodrigues A M; Rogero MM; Bogsan CS; Oliveira Silvia MN; Ihara SM; Araujo SRR; Sanches TRC; Andrade LC; Higa EMS (2014):

Kefir administration reduced progression of renal injury in STZdiabetic rats by lowering oxidative stress. Nitric Oxide, Volume 37, 15, Pages 53-60. 
Reitman $S$ and Frankel $S$ (1957):

Determination of serum alanine and aspartate aminotransferases (ALT \& AST). Clin .Path. Am. J.; 28: 57-63.

Rosa DD; Peluzio MCG; Bueno TP; Cañizares EV; Miranda LS; Dorbignyi BM; Dubí DC; Castaño I.E; Grzeskowiak $\mathbf{L M}$ and Ferreira CLF (2014):

Evaluation of the subchronic toxicity of kefir by oral administration in Wistar rats. Nutr Hosp. 29(6):1352-1359.

\section{Schams D and Karg H (1969):}

Studied über die Spezifität des Radioimmunotests zur Bestimmung des Luteinisierungshormons im Rinderblut. HoppeSeyhr's Z- physiol. Chem. 351, 41.

Sedlak $\mathbf{J}$ and Lindsay $\mathbf{R H}$ (1968):
Estimation of total, protein-bound, and nonprotein sulfhydryl groups in tissue with Ellman's reagent. Anal Biochem.;25:192-205.

Seddik L; TM Bah; A Aoues; M Brnderdour and $M$ Silmani (2010):

Dried leaf extract protects against lead-induced neurotoxicity in Wistar rats. Eur. J. Sci. Res., 42: 139-151.

Sinclair M; Grossmann M; Gow PJ and Angus PW (2015):

Testosterone in men with advanced liver disease: abnormalities and implications. $J$

Gastroenterol Hepatol;30 (2):244-51.

Slinkard $J$ and Singleton VL (1977):

Total phenol analysis: automation and comparison with manual methods. Am. J. Enol. Viticult; 28: 49-55. 
Snedecor CW and Cochran WC (1967):

Statistical methods, 7th Ed., The lowa state Univ. Press. Amer. Lowa, USA.

Songisepp E; Kullisaar T; Huttp P; Elias P; Brilene T; Zilmer M and Mikesaar M (2004):

A new probiotic cheese with antioxidative and antimicrobial activity. J.Dairy Sci. 87, 20132017.

Vaziri ND and Khan M ( 2007):

Interplay of reactive oxygen species and nitric oxide in the pathogenesis of experimental leadinduced hypertension. Clin
Exp Pharmacol Physiol; 34:920-925.

Wilke TJ and Utley DJ (1987):

Total testosterone, free androgenic index and calculated free testosterone by analog RIA method. Clinc.Chem.;33:1372:1375

Zhishen J; Mengcheng $T$ and Jianming W (1999):

The determination of flavonoid contents in mulberry and their scavenging effects on superoxide radicals. Food Chem; 64: 555-559. 
Table (1): Chemical composition (g/100g) of Kefir milk and Kefir grain

\begin{tabular}{|c|c|c|c|c|c|c|c|c|c|}
\hline Sample & $\begin{array}{c}\text { Moisture } \\
\mathbf{\%}\end{array}$ & $\begin{array}{c}\text { C. } \\
\text { protein } \\
\mathbf{\%}\end{array}$ & $\begin{array}{c}\text { T. } \\
\text { lipid } \\
\mathbf{\%}\end{array}$ & $\begin{array}{c}\text { Ash } \\
\mathbf{\%}\end{array}$ & $\begin{array}{c}\text { T. } \\
\text { Carb. } \\
\mathbf{\%}\end{array}$ & $\begin{array}{c}\text { T. } \\
\text { phenol } \\
\mathbf{m g} / \mathbf{g}\end{array}$ & $\begin{array}{c}\text { Flavonoid } \\
\mathbf{m g} / \mathbf{g}\end{array}$ & $\begin{array}{c}\text { PH } \\
\mathbf{\%}\end{array}$ & $\begin{array}{c}\text { Ethanol } \\
\mathbf{\%}\end{array}$ \\
\hline $\begin{array}{c}\text { Kefir } \\
\text { milk }\end{array}$ & 87.62 & 3.03 & 3.15 & 0.043 & 5.77 & 0.84 & 0.16 & 4.9 & 0.065 \\
\hline $\begin{array}{c}\text { Kefir } \\
\text { grain }\end{array}$ & 9.53 & 10.75 & 7.88 & 2.03 & 18.71 & 2.03 & 0.88 & --- & ---- \\
\hline
\end{tabular}

Table (2): Effects of yogurt, kefir milk and kefir grain supplementation on biological parameters on rats intoxicated by lead acetate

\begin{tabular}{|c|c|c|c|}
\hline $\begin{array}{c}\text { Groups } \\
\text { Variable }\end{array}$ & $\begin{array}{c}\text { Weight gain } \\
(\mathbf{g})\end{array}$ & $\begin{array}{c}\text { Feed intake } \\
(\mathbf{g} / \mathbf{d})\end{array}$ & FER \\
\hline C- & $55.80 \mathrm{a} \pm 2.49$ & $12.70 \mathrm{a} \pm 0.51$ & $\mathbf{0 . 1 0 a} \pm \mathbf{0 . 0 0 2}$ \\
\hline N.K. $\mathbf{M}$ & $55.36 \mathrm{a} \pm 2.23$ & $12.74 \mathrm{a} \pm 0.32$ & $\mathbf{0 . 1 0 a} \pm \mathbf{0 . 0 0 2}$ \\
\hline C+ & $19.20 \mathrm{~d} \pm 2.17$ & $7.80 \mathrm{c} \pm 0.39$ & $\mathbf{0 . 0 5} \pm \mathbf{0 . 0 0 5}$ \\
\hline Y & $37.97 \mathrm{c} \pm 0.81$ & $13.18 \mathrm{a} \pm 0.31$ & $\mathbf{0 . 0 6 d} \pm \mathbf{0 . 0 0 2}$ \\
\hline K. M. & $39.80 \mathrm{c} \pm 3.27$ & $11.82 \mathrm{~b} \pm 0.41$ & $\mathbf{0 . 0 7} \mathbf{c} \pm \mathbf{0 . 0 0 5}$ \\
\hline K.G. & $46.80 \mathrm{~b} \pm 3.19$ & $11.86 \mathrm{~b} \pm 0.40$ & $\mathbf{0 . 0 9} \pm \mathbf{0 . 0 0 5}$ \\
\hline
\end{tabular}

Values in each column showed as average having different letters $(a, b, \ldots)$ were significant .

C-: Normal control

N.K. M: Normal+ kefir milk C+: positive control

Y: yogurt

K. M.: kefir milk

K.G.: kefir grain 
Table (3): Effects of yogurt, kefir milk and kefir grain supplementation on kidney functions and liver functions of rats intoxicated by lead acetate

\begin{tabular}{|c|c|c|c|c|c|}
\hline Groups & $\begin{array}{c}\text { Uric acid } \\
\mathbf{m g} / \mathbf{d l}\end{array}$ & $\begin{array}{c}\text { Creatinine } \\
\mathbf{m g} / \mathbf{d l}\end{array}$ & $\begin{array}{c}\text { Urea } \\
\mathbf{m g} / \mathbf{d l}\end{array}$ & $\begin{array}{c}\text { AST } \\
(\mathbf{U} / \mathbf{m l})\end{array}$ & $\begin{array}{c}\text { ALT } \\
(\mathbf{U} / \mathbf{m l})\end{array}$ \\
\hline Variable & $1.97^{\mathrm{c}}$ & $0.58^{\mathrm{c}}$ & $\begin{array}{c}29.12^{\mathrm{c}} \\
\pm 0.81\end{array}$ & $27.17^{\mathrm{d}}$ & $17.83^{\mathrm{d}}$ \\
\pm 0.12 & \pm 0.02 & \pm 1.55 & \pm 1.61 \\
\hline N.K. M & $1.93 \mathrm{c}$ & $0.58 \mathrm{c}$ & $29.20 \mathrm{c}$ & $27.05 \mathrm{~d}$ & $17.75 \mathrm{~d} \pm$ \\
& \pm 0.18 & \pm 0.06 & \pm 0.69 & \pm 2.54 & 1.39 \\
\hline C+ & $3.81 \mathrm{a}$ & $3.42 \mathrm{a}$ & $47.47 \mathrm{a}$ & $55.48 \mathrm{a}$ & $36.22 \mathrm{a}$ \\
& \pm 0.33 & \pm 0.57 & \pm 2.35 & \pm 2.02 & \pm 2.41 \\
\hline Y & $2.65 \mathrm{~b}$ & $1.70 \mathrm{~b}$ & $32.91 \mathrm{~b}$ & $48.42 \mathrm{~b}$ & $26.52 \mathrm{~b}$ \\
& \pm 0.47 & \pm 0.34 & \pm 1.68 & \pm 7.00 & \pm 2.07 \\
\hline K. M. & $2.45 \mathrm{~b}$ & $1.47 \mathrm{~b}$ & $29.55 \mathrm{c}$ & $32.10 \mathrm{c}$ & $20.58 \mathrm{c}$ \\
& \pm 0.31 & \pm 0.41 & \pm 1.06 & \pm 3.81 & \pm 1.00 \\
\hline K.G. & $2.06 \mathrm{c}$ & $0.66 \mathrm{c}$ & $29.84 \mathrm{c}$ & $27.50 \mathrm{~cd}$ & $19.73 \mathrm{~cd}$ \\
& \pm 0.11 & \pm 0.10 & \pm 0.86 & \pm 2.22 & \pm 1.83 \\
\hline
\end{tabular}

Values in each column showed as average having different letters $(a, b, \ldots)$ were significant C-: Normal control

N.K. M: Normal+ kefir milk C+:positive control

Y: Lead acetate + yogurt

K. M.: Lead acetate + kefir milk

K.G.: Lead acetate + kefir grain 
Table (4): Effects of yogurt, kefir milk and kefir grain supplementation on sexual hormonal parameters on rats intoxicated by lead acetate.

\begin{tabular}{|c|c|c|c|}
\hline Groups & FSH & LH & T \\
Variable & $\mathbf{n g} / \mathbf{m L}$ & $\mathbf{n g} / \mathbf{m L}$ & $\mathbf{n g} / \mathbf{m L}$ \\
\hline C- & $155.60 \mathrm{ab}$ & $4.54 \mathrm{a}$ & $25.52 \mathrm{ab}$ \\
& \pm 6.43 & \pm 0.11 & \pm 0.43 \\
\hline N.K. M & $160.88 \mathrm{a}$ & $4.58 \mathrm{a}$ & $26.54 \mathrm{a}$ \\
& \pm 5.60 & \pm 0.04 & \pm 2.29 \\
\hline C+ & $101.46 \mathrm{e}$ & $1.41 \mathrm{e}$ & $11.26 \mathrm{e}$ \\
& \pm 1.48 & \pm 0.03 & \pm 0.46 \\
\hline Y & $122.94 \mathrm{~d}$ & $2.99 \mathrm{~d}$ & $16.83 \mathrm{~d}$ \\
& \pm 1.90 & \pm 0.04 & \pm 0.41 \\
\hline K. M. & $138.69 \mathrm{c}$ & $4.01 \mathrm{c}$ & $22.07 \mathrm{c}$ \\
& \pm 0.44 & \pm 0.03 & \pm 0.63 \\
\hline K.G. & $149.39 \mathrm{~b}$ & $4.19 \mathrm{~b}$ & $24.97 \mathrm{~b}$ \\
& \pm 0.41 & \pm 0.29 & \pm 0.12 \\
\hline
\end{tabular}

Values in each column showed as average having different letters $(a, b, \ldots)$ were significant FSH: Follicle Stimulating Hormone level

LH: Luteinizing hormone T: testosterone.

C-: Normal control

N.K. M: Normal+ kefir milk C+: positive control Y: Lead acetate +yogurt

K. M.: Lead acetate + kefir milk

K.G.: Lead acetate + kefir grain 
Table (5): Effects of yogurt, kefir milk and kefir grain supplementation on antioxidant parameters on rats intoxicated by lead acetate.

\begin{tabular}{|c|c|c|c|}
\hline Groups & $\begin{array}{r}\text { MDA } \\
(\mathbf{n m o l} / \mathbf{g})\end{array}$ & $\begin{array}{c}\text { SOD } \\
(\mathbf{u} / \mathbf{g})\end{array}$ & $\begin{array}{c}\text { GSH } \\
(\mathbf{n m o l} / \mathbf{g})\end{array}$ \\
\hline Variable & $30.20 \mathrm{c}$ & $2.42 \mathrm{~b}$ & $1.90 \mathrm{bc}$ \\
\pm 1.12 & \pm 0.24 & \pm 0.24 \\
\hline N.K. M & $28.19 \mathrm{~d}$ & $3.02 \mathrm{a}$ & $2.32 \mathrm{a}$ \\
& \pm 1.25 & \pm 0.41 & \pm 0.30 \\
\hline C+ & $43.74 \mathrm{a}$ & $0.83 \mathrm{~d}$ & $0.91 \mathrm{e}$ \\
& \pm 1.93 & \pm 0.03 & \pm 0.04 \\
\hline Y & $36.36 \mathrm{~b}$ & $1.83 \mathrm{c}$ & $1.33 \mathrm{~d}$ \\
& \pm 1.42 & \pm 0.19 & \pm 0.04 \\
\hline K. M. & $30.30 \mathrm{c}$ & $2.36 \mathrm{~b}$ & $1.74 \mathrm{c}$ \\
& \pm 1.18 & \pm 0.34 & \pm 0.19 \\
\hline K.G. & $30.92 \mathrm{c}$ & $1.89 \mathrm{c}$ & $2.04 \mathrm{~b}$ \\
& \pm 1.97 & \pm 0.14 & \pm 0.24 \\
\hline
\end{tabular}

Values in each column showed as average having different letters $(a, b, \ldots)$ were significant MDA:- Malondialdehyde SOD:- Superoxide dismutase GSH:- Glutathion C-:Normal control

N.K. M: Normal+ kefir milk C+:positive control Y: Lead acetate + yogurt K. M.: Lead acetate + kefir milk

K.G.: Lead acetate + kefir grain 


\section{Histopathological Examination of the Tests}

\begin{tabular}{|c|c|}
\hline $\begin{array}{l}\text { Pict.(1) the control (-ve) group showing } \\
\text { normal seminiferous tubules, normal } \\
\text { spermatogenic cells and the tubules contain } \\
\text { mature spermatid. }\end{array}$ & atis \\
\hline $\begin{array}{l}\text { Pict.(2) the control (+ ve) group exhibiting } \\
\text { destruction of some spermatogenic cells of the } \\
\text { seminiferous tubules with interstitial edema. H } \\
\text { \& E X } 200\end{array}$ & 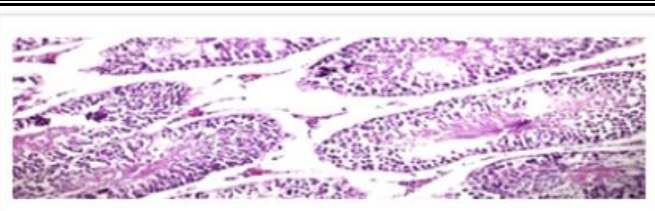 \\
\hline $\begin{array}{l}\text { Pict.(3) normal rat from kefir milk group } \\
\text { showing normal seminiferous tubules, normal } \\
\text { spermatogenic cells and the tubules contain } \\
\text { mature spermatid. }\end{array}$ & $\left.\log ^{3}\right)^{3}$ \\
\hline $\begin{array}{l}\text { Pict.(4) yoghurt group showing, few } \\
\text { degeneration changes in the spermatogenic } \\
\text { cells with separation of the seminiferous } \\
\text { tubules. H \& E X200 }\end{array}$ & $\frac{1}{2}$ \\
\hline $\begin{array}{l}\text { Pict.(5) kefir milk group revealing normal } \\
\text { spermatogenesis with few reduction of mature } \\
\text { sperm in seminiferous tubules H \& E X } 200\end{array}$ & \\
\hline $\begin{array}{l}\text { Pict.(6), kefir grain group showing activation } \\
\text { of spermatogenesis and mature spermatid } \\
\text { tubules H \& E X } 200\end{array}$ & 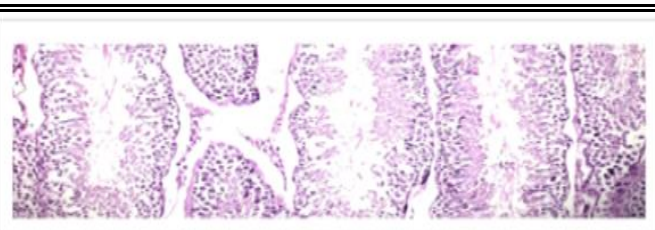 \\
\hline
\end{tabular}




\section{التأثير الوقائي للكفير كبروبيوتيك علي القدرة التناسلية في ذكور الجرذان}

هالة عزت مصطفى الكواوي

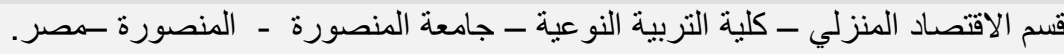

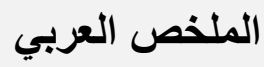

لبيس الهذف من الغذاء اليوم اثباع الجوع وتوفير العناصر الغذائية الضروربية للإنسان

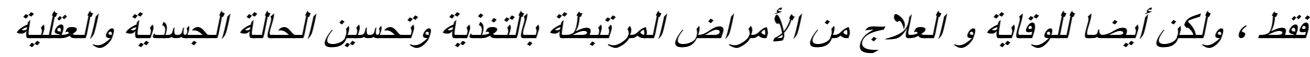

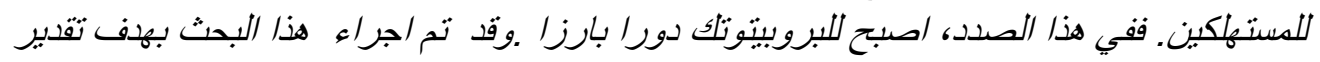

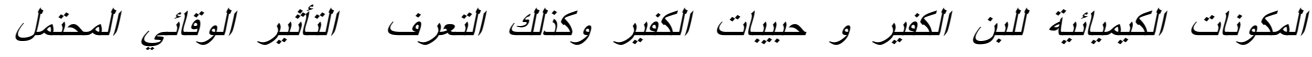

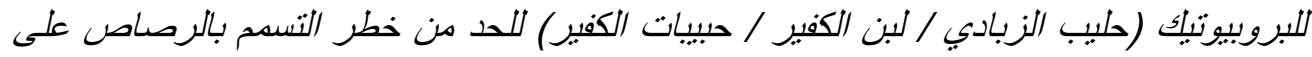

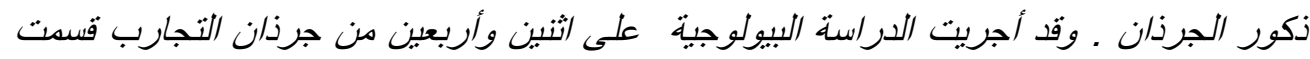

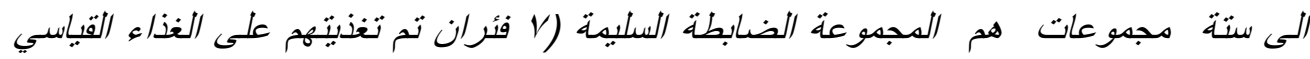

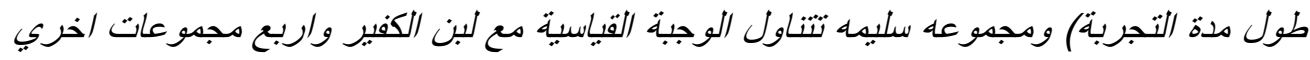

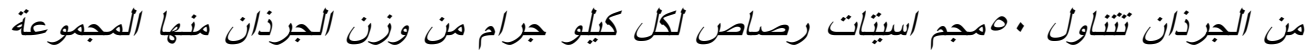

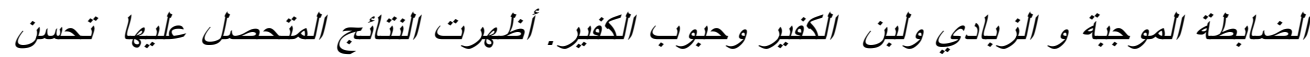

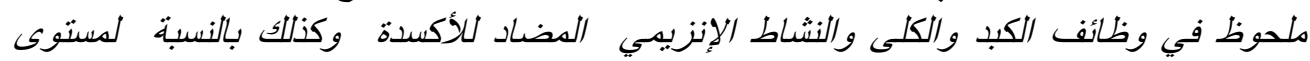

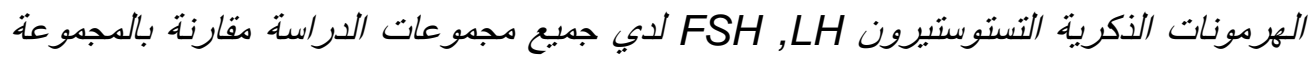

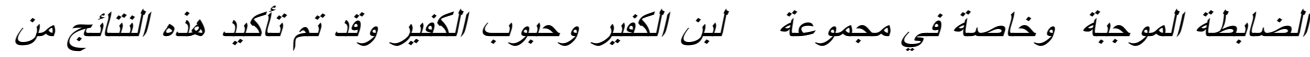

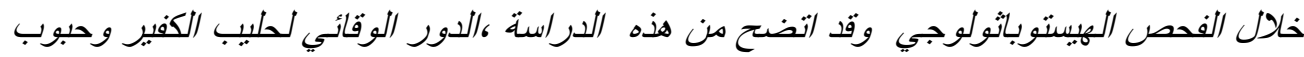

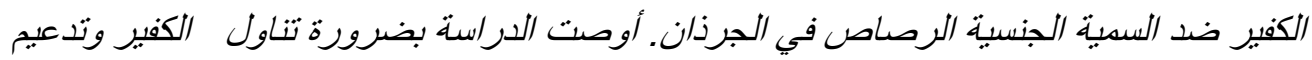

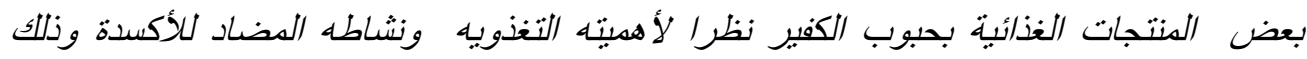

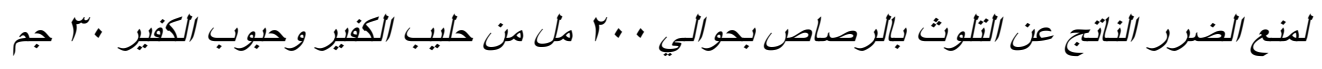
بومبا لون

الكلمات المفتاحية: الكفبر - حبوب الكفير - الزبادي - البروبيوتيك - أسبتات الرصاص السمبة الجنسية السفات النية 